\title{
CITRA PAHLAWAN DALAM SASTRA LISAN DATU ALING DI KABUPATEN TAPIN (TELAAH HERMENEUTIKA)
}

\author{
Novia Winda dan Noor Indah Wulandari \\ Pendidikan Bahasa dan Sastra Indonesia \\ STKIP PGRI Banjarmasin \\ Jalan Sultan Adam, Komplek H. Iyus, No. 18 RT.23 Banjarmasin, \\ Kalimantan Selatan. Kode pos 70121 \\ email: noviawinda05@stkipbjm.ac.id.
}

\begin{abstract}
Abstrak
Dalam sastra lisan Banjar yang berbentuk prosa, seperti kisah-kisah Datu, yaitu cerita yang berhubungan dengan kepercayaan terhadap makhluk halus penjelmaan arwah para datu yang pernah hidup dengan segala keistimewaannya, seperti Datu Aling.Datu Aling memiliki kelebihan yang melebihi manusia pada umumnya.

Penelitian inifokus pada bagaimana Citra Pahlawan dalam Sastra Lisan Datu Aling di Kabupaten Tapin (Telaah Hermeneutika) dengan tujuan untuk mendeskripsikan Citra Pahlawan dalam Sastra Lisan Datu Aling di Kabupaten Tapin (Telaah Hermeneutika).Penelitian ini menggunakan pendekatan kajian hermeneutika dari Ricoeur.Jenis penelitian menggunakan penelitian deskriptif kualitatif.Data penelitian berupa simbol dalam bentuk teks hasil trankripsi dan terjemahan sastra lisan Datu Aling.Informan dalam penelitian ini adalah penjaga makam Datu Aling.Teknik pemeriksaan keabsahan data yang menggunakan triangulasi metode dan teori.

Hasil penelitian ini menemukan Citra Kepahlawanan Datu Aling, yakni:a) memiliki kekuatan prima, cerdas, dan kepekaan yang tajam dalam menghadapi situasi tertentu, b) memiliki kemampuan supernatural yang tinggi, dan c) kehebatan tokoh yang memiliki penolong yang bisa datang tiba-tiba.
\end{abstract}

Kata kunci: citra pahlawan, hermeneutik, datu aling

\section{Pendahuluan}

Cerita rakyat Banjar yang berbentuk lisan ini disebut sastra lisan. Dalam sastra Banjar menurut Sunarti (1978:16) ada sastra lisan yang dimasukkan ke dalam bentuk-bentuk khusus berbentuk prosa, seperti kisah-kisah Datu, yaitu cerita yang berhubungan dengan kepercayaan terhadap makhluk halus penjelmaan arwah para datu yang pernah hidup dengan segala keistimewaannya, seperti Datu Aling, Datu Muning, dan Datu Sanggul.

Datu Aling adalah datu yang ada di Kabupaten Tapin.Tapin adalah salah satu kabupaten yang berada di Kalimantan Selatan. Kabupaten Tapin ini terkenal "Bertabur Ulama (datu-datu)" karena banyaknya ulama yang lahir, bermukim, dan mengajarkan agama Islam di Kabupaten ini sehingga kehidupan masyarakat Tapin sangat agamis. Jika dibandingkan dengan daerah lain di Kalimantan Selatan, Tapin paling banyak melahirkan datu-datu. Hal ini sesuai dengan latar belakang kerajaan Banjar yang beridentitas Kerajaan Islam sehingga memperkuat citra kota danbayangan peta kota yang jelas. 
Atmosfer religius Islam di Tapin dikota Rantau ini menginspirasi Pemerintah Kabupaten Tapin untuk mewujudkan sebuah kawasan baru, yakni kota Rantau Baru yang dilandasi konsep Perancangan Kota Islam (Islamic Urban Design), dengan predikat "Serambi Madinah." Pemerintah Kabupaten Tapin memiliki visi "Rantau Baru Kota Serambi Madinah" dan memiliki salah satu misi "Pembangunan Kawasan Rantau Baru" dengan mewujudkan suasana kehidupan yang Islami sebagai modal dasar penyelenggaraan pembangunan dan kegiatan kemasyarakatan, berdasarkan latar sejarah Tapin Bertabur Ulama (Datu-datu).

Soeratno (2004:241-242) dalam bukunya menyampaikan bahwa dalamsastra melayu citra keluarbiasaan, keunggulan, menakjubkan, mencengangkan, dan mengagumkan dapat diketahui melalui beberapa hal, antara lain: a) kelahiran tokoh, b) fisik yang bagus, wajah tampan, memiliki kekuatan prima, cerdas, dan kepekaan yang tajam dalam menghadapi situasi tertentu, c) memiliki kemampuannatural dan supernatural yang tinggi, d) kehebatan tokoh yang memiliki penolong yc...o bisa datang tiba-tiba, e) mempunyai kemampuan berhubungan dengan makhluk lain, f) mempunyai kemampuan mengubah diri menjadi makhluk lain, dan g) kehebatan tokoh pahlawan juga bisa diketahui melalui cerita kehebatan lawan tokoh tersebut.

Berdasarkan latar belakang yang telah diuraikan, peneliti merasa perlu meneliti tentang “Citra Pahlawan dalam Sastra Lisan Datu Aling di Kabupaten Tapin (Telaah Hermeneutika)”.Fokus penelitian ini adalah bagaimana Citra Pahlawan dalam Sastra Lisan Datu Aling di Kabupaten Tapin (Telaah Hermeneutika).Adapun tujuan penelitian ini adalah untuk mendeskripsikan Citra Pahlawan dalam Sastra Lisan Datu Aling di Kabupaten Tapin (Telaah Hermeneutika).

\section{Metode}

\section{Pendekatan dan Jenis Penelitian}

Penelitian ini menggunakan pendekatan kajian hermeneutika dari Ricoeur,yakni hermeneutika sebagai sistem penafsiran (system of interpretation) sebagai proses penguraian dari isi dan makna yang tampak menuju makna yang tersembunyi dengan objek interpretasi mencakup simbol-simbol dan mitos. Jadi,hermeneutika sebagai ilmu atau sistem penafsiran yang menguraikan isi dan makna simbol-simbol dan mitos yang terdapat dalam teks cerita rakyat/legenda Datu Aling untuk mengungkapkan citra pahlawan tokoh.

Jenis penelitian ini merupakan penelitian deskriptif kualitatif.Bogdan dan Miller (dalam Moleong, 2006:3) mengemukakan bahwa penelitian kualitatif adalah penelitian yang menghasilkan data deskriptif berupa kata-kata tertulis atau lisan dari orang-orang atau perilaku yang diamati.Bagi Satoto (2012:22) tujuan penelitian deskriptif untuk membuat deskripsi secara sistematis, faktual, dan akurat mengenai fakta-fakta populasi atau mengenai lokasi tertentu. 


\section{Teknik Pengumpulan Data}

Teknik pengumpulan data yang digunakan seperti diuraikan Arikunto (1998:100) menyebutkan bahwa metode pengumpulan data adalah cara-cara yang digunakan peneliti untuk mengumpulkan data.Dalam pengumpulan data peneliti menggunakan teknik rekam, teknik simak catat, dan teknik dokumentasi.

Informan dalam penelitian ini adalah penjaga makam Datu Aling.Informan ini masih memiliki hubungan kekerabatan dengan Datu Aling.Informan berasal dari suku Banjar, mengetahui dan memahami cerita tersebut, berdomisili disekitar keberadaan cerita (makam), dan mampu bercerita dengan baik.

\section{Keabsahan Data}

Teknik pemeriksaan keabsahan data yang digunakan dalam penelitian iniadalah triangulasi. Menurut Moleong (2005:330) triangulasi adalah teknik pemeriksaan keabsahan data yang memanfaatkan sesuatu yang lain. Pemeriksaan ini dilakukan untuk membandingkan data dengan sumber lainnya.Penelitian ini menggunakan triangulasi metode dan triangulasi teori.

Triangulasi metode dari Patton (dalam Moleong, 2005:331) dilakukan dengan dua strategi, yaitu: (1) pengecekan derajat kepercayaan penemuan hasil penelitian dari beberapa teknik pengumpulan data dan (2) pengecekan derajat kepercayaan beberapa sumber data dengan metode yang sama. Triangulasi teori dari Linclon dan Guba (dalam Moleong, 2005:331) adalah teknik pemeriksaan keabsahan data berdasarkan anggapan bahwa fakta tidak dapat diperiksa derajat kepercayaannya dengan satu atau lebih teori.Jadi, untuk memeriksa fakta ini diperlukan beberapa teori, sedangkan triangulasi teori menurut Patton dapat dilakukan dengan penjelasan banding (rival explanation).

\section{Hasil dan Pembahasan}

Sastra lisan dipahami sebagai sebuah karya sastra yang disampaikan secara lisan dan turuntemurun.Sastra lisan adalah karya yang penyebarannya disampaikan dari mulut ke mulut secara turun-temurun, ciri-ciri sastra lisan: (1) lahir dari masyarakat yang polos, belum mengenal huruf, dan bersifat tradisional, (2) menggambarkan budaya milik kolektif tertentu, yang tidak jelas siapa penciptanya, (3) lebih menekankan aspek khayalan, ada sindiran, jenaka, dan pesan mendidik, (4) sering melukiskan tradisi kolektif tertentu. Di samping itu ada juga ciri lain, seperti (1) sastra lisan banyak mengungkapkan kata-kata atau ungkapan-ungkapan klise dan (2) sastra lisan sering bersifat menggurui (Endraswara, 2013:151).

Dalam sastra Banjar menurut Sunarti (1978:16) ada juga sastra lisan yangdimasukkan ke dalam bentuk-bentuk khusus berbentuk prosa, sebagai berikut: 
a. Kisah-kisah kepahlawanan (sage), menceritakan kepahlawanan pribadi-pribadiyang menentang ketidak-adilan, seperti Kisah-kisah Panji Utama,Panji Kuripan, Anak Nang Dibuang, Tutur Candi, dan Si Pujung

b. Kisah-kisah yang berhubungan dengan kejadian (mitos), ialah kisah-kisahajaib sekitar manusia yang menjelma menjadi binatang karena kutukan ataucobaan dari Tuhan, seperti kisah Raja Baung dan Kucing Handak Balaki Raja.

c. Kisah-kisah Datu, yaitu cerita yang berhubungan dengan kepercayaanterhadap makhluk halus penjelmaan arwah para datu yang pernah hidupdengan segala keistemewaannya, seperti Datu Sanggul dan Datu Pujung.

Jadi, sastra lisan Banjar lahir pada masyarakat yang polos dan diketahui secara turuntemurun.Sastra lisan Datu Aling merupakan sastra lisan yang berbentuk prosa.Penelitian ini meneliti sastra lisan Datu Aling berdasarkan citra kepahlawanannya.

Citra keluarbiasaan, keunggulan, menakjubkan, mencengangkan, dan mengagumkan dalam sastra melayu menurut Soeratno (2004: 241-242) dapat diketahui melalui: a) kelahiran tokoh, b) fisik yang bagus, wajah tampan, memiliki kekuatan prima, cerdas, dan kepekaan yang tajam dalam menghadapi situasi tertentu, c) memiliki kemampuan natural dan supernatural yang tinggi, d) kehebatan tokoh yang memiliki penolong yang bisa datang tiba-tiba, e) mempunyai kemampuan berhubungan dengan makhluk lain, f) mempunyai kemampuan mengubah diri menjadi makhluk lain, dan g) kehebatan tokoh pahlawan juga bisa diketahui melalui cerita kehebatan lawan tokoh tersebut.

Citra pahlawan Datu Aling ini dikaji berdasarkan kajian Hermeneutika Ricoeur.Hermeneutika berkaitan dengan bahasa karena kegiatan manusia selaluberkaitan dengan bahasa sebagai media menginterpretasikan sesuatu yangdimaksud.Berikut ini hermeneutika menurut Ricoeur (2002:235).

\footnotetext{
Bahasa merupakan syarat utama bagi semua pengalaman manusia.Kita bergaul dengan masyarakat menggunakan bahasa, mengungkapkan diri melalui bahasa, memahami sesuatu dengan istilah-istilah yang terdapat dalam bahasa. Namun, bahasa juga memiliki kelemahan, sebab kita memahami bahasa melalui bahasa, maka kita bisa salam paham atau tidak memahami bahasa tersebut. Melalui hermeneutika, segala masalah yang terdapat dalam filsafat bahasa dapat dijawab melalui interpretasi.
}

Peneliti sependapat dengan definisi hermeneutika menurut Ricoeur (dalam Ahmala, 2004:24) yakni hermeneutika sebagai sistem penafsiran(system of interpretation) sebagai proses penguraian dari isi dan makna yangtampak menuju makna yang tersembunyi dengan objek interpretasi mencakup simbol-simbol dan mitos. Peneliti dan penafsir teks harus mampu memproyeksikan diri dalam memahami teks itu sendiri.

\section{Citra Kepahlawanan Datu Aling}


Berdasarkan sastra lisan Datu Aling peneliti menemukan tiga citra kepahlawanan Datu Aling, yakni:a) memiliki kekuatan prima, cerdas, dan kepekaan yang tajam dalam menghadapi situasi tertentu, b) memiliki kemampuan supernatural yang tinggi, danc) kehebatan tokoh yang memiliki penolong yang bisa datang tiba-tiba.

\section{Memiliki kekuatan prima, cerdas, dan kepekaan yang tajam dalam menghadapi situasi tertentu}

Menurut cerita, Datu Aling ini hidup sebagai seorang petani, namun memilkisejumlah besar perahu (Jukung-Banjar) sebagai alat transportasi sungai dan alat berniaga. Hasil pertanian yang Datu Aling miliki, menjadikan beliau sebagai orang terkaya di daerah Muning. Beliau dikenal sebagai sosok yang sholeh dan sering membantu fakir miskin.Hal ini membuat Datu Aling menjadi terkenal dan tokoh terhormat dikalangan masyarakat luas. Datu Aling juga dikenal sebagai tokoh masyarakat yang memiliki kekuatan prima. cerdas, dan kepekaan yang tajam dalam menghadapi situasi tertentu.Hal ini terbukti dari cara beliau memimpin pasukan perang melawan penjajah Belanda di daerah Muning. Perhatikan kutipan berikut:

"Jadi sidin tu yang jadi kapalanya pas mamimpin perang malawan panjajah.Sidin yang maatur strategi perang.Sidin jua yang malatih anak buah perang. Waktu itu pas masih karajaan Tamjidilah. Sidin bapirasat pacang ada nang bahianat. Iya sidin maulah pasukan."

"Jadi, Beliau memimpin perang melawan penjajah.Beliaumengatur strategi perang.Beliau juga yang melatih prajurit untuk berperang.Peperangan ini terjadi ketika Raja Tamjidilah berkuasa di Kerajaan Banjar.Datu Aling memilikifirasat bahwaakan ada yang berkhianat pada Kerajaan Banjar. Oleh sebab itu,Beliau membentuk pasukan perang."

Dari kutipan di atas, tampak bahwa datu Aling memiliki kekuatan yang prima.dalam memimpin pasukan untuk berperang.Beliaumemiliki sifat cerdas. Hal ini terlihat dari cara beliau mengatur strategipeperangandengan beragam kondisi prajurit. Beliau juga memiliki kepekaan yang tajam.Hal ininampak ketika Datu Aling memiliki firasat akan adanya penghianat dari dalam kerajaan.Sehingga beliau membentuk pasukan perang untuk melawan penjajahan Belanda.

Kecerdasan dan kepekaan yang tajam dimiliki Datu Aling ketika menghadapi situasi peperangan.Beliau mampu mengumpulkan tokoh-tokoh yang berada di empat kabupaten yang berbeda.Hal ini terbukti dari peran beliau sebagai inisiator perang Banjar melawan penjajah Belanda yang terjadi di daerah Muning, Kabupaten Rantau.Seperti tergambar pada kutipan berikut:

\footnotetext{
"Beliau adalah seorang inisiator, artinya seorang pencetus perang Banjar di mana beliau itu sami, artinya diberi oleh Allah kelebihan artinya mampu mengumpulkan tokoh-tokoh yang ada di Banua Ampat nah seperti Banua Padang, Banua Gadung, Banua Halat, dan Banua Parigi”,

"Beliau adalah seorang inisiator, artinya seorang pencetus perang Banjar, beliau diberi Allah kelebihan, yakni mampu mengumpulkan tokoh-tokoh yang ada di Banua Empat(empat kabupaten), seperti Banua Padang, Banua Gadung, Banua Halat, dan Banua Parigi”
} 


\section{Memiliki Kemampuan Supernatural yang Tinggi}

Datu Aling terkenal dengan istiqamahnya dalam beribadah kepada Allah Swt. Beliau juga sering berkhalwat untuk semakin mendekatkan diri kepada Ilahi di pegunungan Loksado Kabupaten Kandangan.Konon Datu Aling memiliki peninggalan sumur gaib yang tampak hanya pada 14 bulan purnama malam Jumat.sumur gaib itu airnya tidak lebih sejengkal tingginya, namun tidak habis dimandikan oleh beratus-ratus orang. Hal ini membuktikan bahwa Datu Aling memiliki kemampuan supernatural yang tinggi.Simak kutipan berikut.

"Sidin nih nang ulun dangar, ujar pakayian jua.Bila handak perang disuruh sidin anak buah tu mandi di sumur sidin. Ia taguh, tahan ditumbak panjajah. Sampai wahini sumur tuh kada biasa karing nang kaya apa haja kamaraunya. Sampai wahini tiap malam ka ampat balas pas kana malam Jumahat banyak haja lakian mandian di sumur nih supaya pas madam ka banua urang kada papa atau kada diapai urang”

"Beliau ini menurut cerita yang saya dengar dari kakek saya.Ketikaakanberperang, beliau meminta prajurit untuk mandi di sumur beliau. Sehingga prajurit akan kebal ketika ditombak oleh penjajah. Sampai sekarang sumur tersebut tidak pernah kering walaupun musim kemarau. Sampai sekarang setiap malam keempat belas malam Jumat bulan purnama banyak laki-laki yang mandi di sumur tersebut agar ketika merantau ke negeri orang akan selamat."

Dari kutipan di atas, dapat disimpulkan bahwa Datu Aling memiliki kekuatan supernatural yang tinggi. Terbukti dari prajurit beliau yang memiliki ilmu kebal. Murid beliau yang mandi di sumur tersebut memiliki kekebalan ketika berperang melawan penjajah.Berarti Datu Aling memiliki kekuatan supernatural yang lebih tinggi daripada murid-muridnya.Selain itu, Datu Aling juga dikenal masyarakat dapat berpindah tempat dalam waktu yang sangat cepat. Seperti pada kutipan berikut:

\footnotetext{
"Mulai sidin hidup, bila musim haji sidin nih ada di Makkah.Sidin nang manyambut buhan banua nang baibadah di Makkah. Sampai wahini, kita banar ai kada pinandu lawan sidin. Jadi, mun handak ziarah ka makam sidin nih jangan pas musim haji.”

"Ketika beliau masih hidup, apabila musim haji beliau ada di Mekkah.Beliau selalu menyambut kedatangan orang Kalimantan Selatanyang beribadah di Mekkah.Hal ini masih berlaku sampai sekarang.Hanya kita saja yang tidak mengenal wajah beliau. Jadi, apabila berziarah ke makam beliau janganpada bulan haji."
}

Kemampuan supernatural yang beliau miliki merupakan wujud dari karamah yang diberikan oleh Allah Swt. Orang awam tidak mungkin ke Mekkah hanya dalam hitungan detik saja. Diperlukan waktu berhari-hari untuk bisa menuju Mekkah, itu pun dibantu dengan transportasi udara. Sedangkan, pada zaman dahulu belum ada transportasi udara. Beliau pergi ke Mekkah menggunakan kemampuan supernatural yang dimilikinya. 


\section{Memiliki Penolong yang Datang Tiba-tiba}

Salah satu ciri seseorang memiliki citra kepahlawanan adalah memiliki penolong yang bisa datang tiba-tiba.Wujud pernolong Datu Aling ini bias berupa dari benda-benda yang ada di sekitar beliau. Seperti pada kutipan berikut:

"Sidin nih baisi parang bungkul. Parang bungkul tuh ganal. Jadi, buhan garombolan bahari handak manyalukut rumah sidin. Jadi, ketika handak disalukutnya pakai juluk sarabanyaai pokoknya handak manggusanglah, maka hatap rumbia kada mau jua gusang dan parang bungkul itu bagarak-garak. Sampai wahini parang itu disimpan dan bagarak bila ada nang jahat handak masuk ka rumah.”

"Beliau memiliki parang bungkul. Parang bungkulit berukuran besar. Jadi, ketika gerombolan penjahat ingin membakar rumah beliaumenggunakan tongkat panjang dan mengenai atap rumah beliau yang terbuat dari daun pelepah aren. ternyata tidak bisa terbakar dan parang bungkul tersebut bergerak-gerak. Sampai sekarang parang tersebut disimpan dan bergerak-gerak apabila ada orang jahat yang inginmemasuki ke rumah.

Dari kutipan di atas, nampak bahwa Datu Aling mendapatkan pertolongan tiba-tiba dari benda yang bernama parang bungkul.Ketika gerombolan penjahat membakar rumah beliau. Harusnya rumah tersebut dengan mudah akan terbakar karena atap rumah terbuat dari daun pelepah aren.Tetapi, yang terjadi malah sebaliknya.

\section{Simpulan}

Kisah Datu Aling merupakan sastra lisan Banjar berbentuk prosa, cerita yang berhubungan dengan kepercayaan pada Datu yang pernah hidup dengan segala keistemewaannya. Datu Aling adalah salah satu Datu dari Kabupaten Tapin yang memiliki berbagai keistemewaan.

Citra keluarbiasaan, keunggulan, menakjubkan, mencengangkan, dan mengagumkan dalam dalam kisah Datu Aling ini dapat diketahui melalui: a) kelahiran tokoh, b) fisik yang bagus, wajah tampan, memiliki kekuatan prima, cerdas, dan kepekaan yang tajam dalam menghadapi situasi tertentu, c) memiliki kemampuan natural dan supernatural yang tinggi, d) kehebatan tokoh yang memiliki penolong yang bisa datang tiba-tiba, e) mempunyai kemampuan berhubungan dengan makhluk lain, f) mempunyai kemampuan mengubah diri menjadi makhluk lain, dan g) kehebatan tokoh pahlawan juga bisa diketahui melalui cerita kehebatan lawan tokoh tersebut.

Penelitian Citra Pahlawan dalam Sastra Lisan Datu Aling di Kabupaten Tapin (Telaah Hermeneutika) ini menemukan 4 Citra Pahlawan, yakni:a) memiliki kekuatan prima, cerdas, dan kepekaan yang tajam dalam menghadapi situasi tertentu, b) memiliki kemampuan supernatural yang tinggi, dan c) kehebatan tokoh yang memiliki penolong yang bisa datang tiba-tiba. 


\section{Daftar Pustaka}

Danandjaya, J. (1982). Folklor Indonesia, Ilmu Gosip, Dongeng, dan Lain-lain.Jakarta: Grafiti.

Moleong, L. J. (2005). Metode Penelitian Kualitatif. Bandung: PT Remaja Rosdakarya.

Mulyono, E. dkk.(2013). Belajar Hermeneutika dari Konfigurasi Filosofis Menuju Praksis Islam Studies.Jogjakarta: IRCisoD.

Ong. W. J. (1989). Orality and Literacy: The Technologizing of the Word. London and New York: T. J. Press (Padstow) Ltd, Padstow, Cornwall.

Pusat Bahasa Depertemen Pendidikan Nasional.(2004). Sastra Melayu Lintas Daerah.Jakarta:Pusat Bahasa Depertemen Pendidikan Nasional.

Ratna, N.K. (2010). Sastra dan Cultural Studies: Representasi Fiksi danFakta. Yogyakarta: Pustaka Pelajar.

Safwan, A. N. M. M. (2007). 100 Tokoh Kalimantan. Kandangan:Sahabat.

Satoto, S.(2012). Metode Penelitian Sastra. Surakarta: Yuma Pressindo.

Soeratno, dkk. 2004. Sastra Melayu Lintas Daerah. Jakarta: Pusat Bahasa Depertemen Pendidikan Nasional.

Suharsimi,A. (1998).Prosedur Penelitian: Suatu Pendekatan Praktek. Jakarta: Rineka Cipta.

Sunarti, dkk.(1978). Sastra Lisan Banjar.Jakarta: Pusat Pembinaan dan Pengembangan Bahasa Depertemen Pendidikan dan kebudayaan.

Winda, N. (2016).Legenda Datu-datu Kabupaten Banjar.Banjarmasin: Jurnal PTK dan Pendidikan IAIN Antasari.Vol.2 No. 1. Januari-Juni 2016:31-39. 